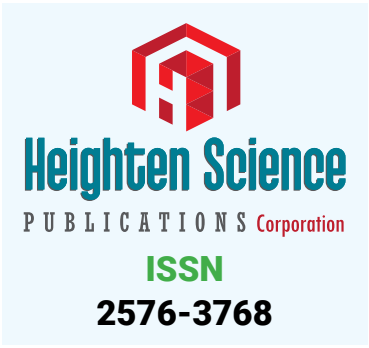

*Address for Correspondence: Srishti Singh, Department of Environmental Engineering and Water Technology, IHE-Delft Institute for Water Education, 2601DA Delft, Netherlands, Email: Srishti24007@gmail.com

Submitted: 30 May 2019 Approved: 11 June 2019 Published: 12 June 2019

Copyright: (c) 2019 Singh S. This is an open access article distributed under the Creative Commons Attribution License, which permits unrestricted use, distribution, and reproduction in any medium, provided the original work is properly cited

D) Check for updates
Research Article

\section{Biodegradation of waste streams containing benzene, toluene, ethylbenzene and xylene (BTEX): Practical implications and brief perspectives}

\author{
Srishti Singh* \\ Department of Environmental Engineering and Water Technology, IHE-Delft Institute for Water \\ Education, 2601DA Delft, Netherlands
}

\section{Introduction}

Benzene (B), toluene (T), ethylbenzene (E) and xylene (X), collectively named as BTEX are mono-aromatic ring compounds with a 6-carbon benzene ring. Due to the presence of the aromatic ring, these compounds, especially benzene, are generally considered to be non-reactive species [1]. However, they are known to undergo hydrogenation and certain substitution reaction depending on the prevailing environmental conditions. Their solubility in water is usually low (i.e. relatively hydrophobic in nature) due to the low octanol-water partition coefficient $\left(K_{\text {ow }}\right)$ values which favour hydrophilic dissolution [2]. BTEX compounds are relatively insoluble in water and in some situations, their levels have been recorded at up to $1000 \mathrm{mg} / \mathrm{L}$, which is much higher than the allowed maximum contaminant level of $0.005 \mathrm{mg} / \mathrm{L}$ for B, $1 \mathrm{mg} / \mathrm{L}$ for T, $0.7 \mathrm{mg} / \mathrm{L}$ for $\mathrm{E}$, and a total of $10 \mathrm{mg} / \mathrm{L}$ for all three forms of X [3]. They are released into the natural environment (air, water, soil and sediments) due to landfill leaching, underground storage tanks, accidents during oil transportation and pipeline leakage from petroleum and chemical industries [4]. BTEX compounds are transported through several metres at oil-spill sites causing them to be persistent pollutants in both soil and water environments [5]. The persistence presence of BTEX in air and the transportation to water bodies has been reported as a result of rainfall [6]. BTEX compounds exists together in the environment suggesting that their toxicity is amplified through their interactions with one another. The composition of BTEX in gasoline is: $\mathrm{m}$-xylene (31\%), toluene (26\%), o-xylene (12\%), ethylbenzene $(11 \%)$, benzene (11\%), $p$-xylene (9\%). BTEX are harmful to human and aquatic life due to its inherent toxic and carcinogenic properties. Acute exposure can cause tiredness, dizziness, headache, loss of coordination, skin, sensory irritation, chronic kidney disease and also affect the liver and blood system [7]. BTEX compounds can be released from a variety of sources such as petrochemical industry waste streams, household wastes, municipal landfills as well as groundwater plumes, especially when they are located at a considerable distance from an oil spill site [8,9]. BTEX are also few of the compounds responsible for the formation of ground level ozone and are considered as priority environmental pollutants by the US-EPA [10].

\section{Practical application}

Biodegradation of BTEX has proven to be a cost-efficient and environmentally friendly treatment technique for the removal of BTEX from contaminated water, soil, 
sediment and air environments [11]. As mentioned previously, BTEX are released from the petroleum, chemical and oil industries as they are spread in the environment due to accidental leakage and due to lack of treatment of these industrial effluents. The persistence of BTEX compounds in groundwater plumes is troublesome, especially in vulnerable regions like Africa and South-East Asia where drinking wells and boreholes for potable and other uses is high. The health risks posed as a result of such chemical persistence cannot be overstated. Bioremediation and biodegradation of oil spill has been in practice for many years now. Two of the greatest oil spills in history, i.e. Exxon Valdez spill in 1989 [12] and BP Deepwater Horizon spill in 2010 [13], had used bioremediation as a technique to reduce the environmental impacts and increase the rate of petroleum biodegradation.

\section{Future research}

Bioremediation is very feasible and effective technology for the treatment of oil containing BTEX sites and is highly effective for practical applications [14]. However, there are factors that make the process undesirable. One such factor is the duration of the bioremediation process. Therefore, nanotechnology based bioprocesses can be applied in treating BTEX contaminated wastewater or waste gases. Besides, nanoparticles have proven ability to remove pathogens in water, adsorb priority water pollutants and degrade chlorination by-products [15]. For cheaper option, research could be done on biosorbents which can be synthesized from green raw materials and green wastes. One such example is the application of tannin-based adsorbents. They are water soluble and it has been reported that they can be converted into insoluble gels and matrices for widespread environmental applications [16]. Tannins are mostly applied in the field of nutrition and cosmetics where they are used as an astringent. They have not been explored for wastewater or waste gas treatment, although the use of biochar produced from various raw materials including domestic sewage sludge have recently found major applications in various domains of environmental engineering. Bacelo et al. [17] reported that tannin-based adsorbents have a naturally high affinity for heavy metals, dyes, and other organic and inorganic pollutants in aqueous solution, indicating a need to investigate the application of these compounds for the removal of mono-aromatic hydrocarbons in water and waste gas steams. The sources for tannin based adsorbents are agricultural products such as leaves and tree barks that are often discarded as a waste in developing countries [18]. Removal of BTEX has traditionally been achieved by mixed cultures of bacteria and the use of fungi has been recognized only recently. There are advantages of using fungi over most bacteria as fungi is readily adaptable to adverse environmental conditions of low moisture and low $\mathrm{pH}$ [19]. Thus, it is important to examine their resilience and activity to tolerate high concentrations of pollutants present in contaminated environments in order to better understand and optimize the mechanisms of remediation using emerging techniques and materials [20]. For treating point source contaminants, bioreactors can be used because temperature, $\mathrm{pH}$, nutrient levels, and agitation can be controlled in constructed batchfed or continuously fed reactors, microbial activity and thus contaminant degradation can be optimized [21].

\section{Conclusion and Perspectives}

BTEX are volatile compounds with high solubility and toxicity. The main source of BTEX contaminated water and waste gas is improper storage and leakage of gasoline and BTEX chemicals from faulty and ill maintained underground storage tanks. Its exposure to humans can occur by drinking water from contaminated wells or by inhalation (exposure to BTEX contaminated water via showering or laundering). Acute exposure can cause skin and sensory irritation and can affect the central nervous system and respiratory system. Therefore, it is important to remove BTEX from the environment and it could be done by using various techniques such as bioremediation, adsorption and nanotechnology. From an economic point of view, bioremediation is the 
best option but it has been reported that it takes longer time to remove the pollutants from the contaminated sites (e.g. oil spills and leakage from storage tanks). In such cases, nanotechnology and tannin based adsorbents could be used to remove BTEX and other volatile pollutants; however, pilot-scale and semi-industrial scale testes should be carried out before applying these materials in real (harsh) environments.

\section{References}

1. Bunnett JF, Draper F Jr, Ryason PR, Noble P Jr, Tonkyn RG, et al. Comparative activation of nucleophilic substitution in 4-substituted-2-nitrochlorobenzenes. J Am Chem Soc. 1953; 75: 642645. Ref.: http://bit.ly/2R5LbvY

2. Anderson MA. Removal of MTBE and other organic contaminants from water by sorption to high silica zeolites. Environ Sci Technol. 2000; 34: 725-727. Ref.: http://bit.ly/2WzA6cl

3. Su F, Lu C, Johnston KR, Hu S. Kinetics, thermodynamics, and regeneration of BTEX adsorption in aqueous solutions via $\mathrm{NaOCl}$-oxidized carbon nanotubes. Environanotechnology. 2010; 71-97. Ref.: http://bit.ly/2Zk9HfW

4. Borden RC, Daniel RA, LeBrun LE, Davis CW. Intrinsic biodegradation of MTBE and BTEX in a gasolinecontaminated aquifer. Water Resources Research. 1997; 33: 1105-1115. Ref.: http://bit.ly/2Wxogj4

5. Cozzarelli IM, Bekins BA, Baedecker MJ, Aiken GR, Eganhouse RP, et al. Progression of natural attenuation processes at a crude-oil spill site: I. Geochemical evolution of the plume. J Contam Hydrol. 2001; 53: 369-385. Ref.: http://bit.ly/2KHCTte

6. Dutta C, Som D, Chatterjee A, Mukherjee AK, Jana TK, et al. Mixing ratios of carbonyls and BTEX in ambient air of Kolkata, India and their associated health risk. Environ Monit Assess. 2009; 148: 97107. Ref.: http://bit.ly/2X3guwP

7. Mitra S, Roy P. BTEX: A serious ground-water contaminant. Res J Environ Sci. 2011; 5: 394-398. Ref.: http://bit.ly/2wMQDdP

8. El-Naas MH, Acio JA, El Telib AE. Aerobic biodegradation of BTEX: progresses and prospects. J Environ Che Eng. 2014; 2: 1104-1122. Ref.: http://bit.ly/2XFSg98

9. Bekins BA, Cozzarelli IM, Godsy EM, Warren E, Essaid HI, et al. Progression of natural attenuation processes at a crude oil spill site: II. Controls on spatial distribution of microbial populations. $J$ Contam Hydrol. 2001; 53: 387-406. Ref.: http://bit.ly/2MCvmhK

10. Yadav JS, Reddy CA. Degradation of benzene, toluene, ethylbenzene, and xylenes (BTEX) by the lignin-degrading basidiomycete Phanerochaete chrysosporium. Appl Environ Microbiol. 1993; 59: 756-762. Ref.: http://bit.ly/2KIP2y2

11. Jo MS1, Rene ER, Kim SH, Park HS. An analysis of synergistic and antagonistic behavior during BTEX removal in batch system using response surface methodology. J Hazard Mater. 2008; 152: 12761284. Ref.: http://bit.ly/2WylwSC

12. Peterson $\mathrm{CH}$, Rice SD, Short JW, Esler D, Bodkin JL, et al. Long-term ecosystem response to the Exxon Valdez oil spill. Science. 2003; 302: 2082-2086. Ref.: http://bit.ly/2l8FzOz

13. Atlas RM. Petroleum biodegradation and oil spill bioremediation. Marine Pollution Bulletin. 1995; 31 : 178-182. Ref.: http://bit.ly/2X2olFy

14. Díaz MP, Boyd KG, Grigson SJ, Burgess JG. Biodegradation of crude oil across a wide range of salinities by an extremely halotolerant bacterial consortium MPD-M, immobilized onto polypropylene fibers. Biotechnol Bioeng. 2002; 79: 145-153. Ref.: http://bit.ly/2MFdAub

15. Shen YF, Tang J, Nie ZH, Wang YD, Ren $\mathrm{Y}$, et al. Preparation and application of magnetic $\mathrm{Fe}_{3} \mathrm{O}_{4}$ nanoparticles for wastewater purification. Separation and Purification Technology. 2009; 68: $312-$ 319. Ref.: http://bit.ly/2XGPWyK

16. Nakano $Y$, Takeshita $K$, Tsutsumi T. Adsorption mechanism of hexavalent chromium by redox within condensed-tannin gel. Water Res. 2001; 35: 496-500. Ref.: http://bit.ly/2WvDLmG

17. Bacelo HA, Santos SC, Botelho CM. Tannin-based biosorbents for environmental applications - a review. Chem Eng J. 2016; 303: 575-587. Ref.: http://bit.ly/2MFe03J

18. El Sissi HI, Saleh NAM, El Sherbeiny AEA, El Ansary MAI. Local plants as potential sources of tannins and the isolation of their free and combined sugars. Qualitas Plantarum et Materiae Vegetabiles. 1965; 12: 262-268. Ref.: http://bit.ly/2Iz3lm5

19. Harms $H$, Schlosser $D$, Wick LY. Untapped potential: exploiting fungi in bioremediation of hazardous chemicals. Nat Rev Microbiol. 2011; 9: 177-192. Ref.: http://bit.ly/2lxxsdv 
20. Pan B, Xing B. Adsorption mechanisms of organic chemicals on carbon nanotubes. Environ Sci Technol. 2008; 42: 9005-9013. Ref.: http://bit.ly/2MEZg4Q

21. Mareddy AR, Shah A, Davergave N. Environmental impact assessment: theory and practice, Butterworth-Heinemann, Oxford, United Kingdom. 2017; Ref.: http://bit.ly/217VmNN 